\title{
Patrícia Campos Mello (2020), The Hate Machine: notes from a reporter on fake news and digital violence [A máquina do ódio: notas de uma repórter sobre fake news e violência digital]. São Paulo: Companhia das Letras. Language: Portuguese Brazilian. ISBN-10: 853593362X. Pbk, 296 pages
}

\section{Rafiza Varão ${ }^{1}$}

Accepted: 13 July 2021 / Published online: 26 July 2021

(c) The Author(s), under exclusive licence to Springer Nature Limited 2021
In The Hate Machine: notes from a reporter on fake news and digital violence (2020), award-winning journalist Patrícia Campos Mello sheds light on the rapid spread of fake news in Brazil, and its profound impact on the political landscape. The book traces the history of resentment, propaganda and misinformation in South America's largest country, illustrating the operationalization of fake news in the political warfare of Brazil's last major presidential election. Beyond the Brazilian case, The Hate Machine: notes from a reporter on fake news and digital violence reflects on the trajectory of misinformation, where politics has become inextricably bound to social media, and legacy media often adopt lies as a matter of strategy.

Mello opens the book by detailing that she was herself a target of false information and an extensive smear campaign on social media in 2019, due to her investigative reporting on then-presidential candidate Jair Bolsonaro. From then on, Mello's ordeal intensified, with President Bolsonaro himself targeting her, stating, 'She wanted a scoop. She wanted to get a scoop against me by any price' (Soares, 1). In addition to the insults directed at her, Mello's family also received several threats. The Hate Machine: notes from a reporter on fake news and digital violence thus addresses the impact of disinformation from the inside, providing a firsthand account of the ideology behind the use of fake news in advancing right-wing techno-populist agendas.

In the first chapter, 'The election of WhatsApp in Brazil', the book presents a report of the amount of fake news used during the election period, highlighting two of the most

Rafiza Varão

rafiza@unb.br

1 Communication College, University of Brasília, Brasília, Brazil prominent examples: the case of the so-called gay kit and the case of the 'piroca bottle' ('piroca' is a Brazilian slang term referring to the male sexual organ). These two emblematic fake news cases focused on moral principles that the far right used to demonize their opponents, claiming that their goals were to turn all citizens gay, by instructing children how to be homosexual.

In this landscape of fake news on social media, the smear campaign against Mello was the best form of defence by candidates during the election against her investigative reports. In the second chapter, 'Murder of reputations, a new form of censorship', Mello details the extent of the smear campaign against her, including slanderous YouTube videos that suggested Mello was a prostitute. The chapter underscores the intensity of this campaign, which resulted in Mello needing, for the first time to be accompanied by bodyguards in her own country.

In the third chapter, 'Alternative facts and the rise of populists in the world', Mello traces a short history of the relationship between the rise of techno-populism, misinformation and fake news not only in Brazil but also in other countries, such as the Philippines and Hungary. In this chapter, Mello makes evident that techno-populism essentially feeds on the discourse in which the truth is no longer one of the necessary beliefs that guide us in a society full of insecurities, as was previously established by Enlightenment scientists in the eighteenth century. Amid the ocean of uncertainties, these new beliefs are reinforced by far right ideologies and significantly amplified by algorithmic logics. Mello cites the recent Cambridge Analytica scandal, in which the data mining of 50 million social media users played a key role in the election of Donald Trump and in Brexit.

The final chapter discusses how Bolsonaro, Orbán and other far right politicians around the world are intent on 
discrediting independent media outlets. Consequently, the 'truth' would only pass through official channels and would therefore be aligned with the heads of state, deeming everything else a lie. In this scenario, independent outlets are economically suffocated in order to threaten their survival, daily offenses against the press are perpetuated and are repeated by ordinary citizens, and continuous attempts are made to hinder access to information of public interest regarding government officials.

We saw all of this occur amid the coronavirus pandemic, and it is on that note that Mello concludes The Hate Machine: notes from a reporter on fake news and digital violence, wondering whether Covid-19, which saw an increase in demand for journalistic information, would save journalism, returning it to a place of honour for objective speech. A few months after the publication of Mello's book, this is an answer that we do not yet have. As the contamination curve begins to slow in most of Brazil, it seems, however, that the populist, denialist and anti-press narrative has strengthened again. But the outcome remains uncertain.

Regarding The Hate Machine: notes from a reporter on fake news and digital violence, however, there are many certainties. More journalistic than academic, the book provides a comprehensive look at the reality of politics that is now organized through social networks, as well as the role of fake news and disinformation in the ongoing battle for the hearts and minds of voters. In addition, it reveals how independent journalism, despite its problems, is still fundamental to the functioning of a democratic society. Mello paints a brief history of contemporary Brazil as it is still unfolding, and provides an inside look at those who, although victimized, still continue to fight for freedom of the press. The book is valuable for students and researchers interested in an indepth understanding of contemporary problems concerning politics, populism, authoritarianism and social media.

\section{Reference}

Soares, Ingrid. 2020. Bolsonaro, sobre repórter da Folha: "Ela queria dar um furo"; jornal reage: "ela queria dar um furo a qualquer preço contra mim', disse o presidente da república nesta quintafeira, entre risos. Correio Braziliense, 18 february. https://www. correiobraziliense.com.br/app/noticia/politica/2020/02/18/inter na_politica,828834/bolsonaro-sobre-reporter-da-folha-ela-queria-dar-um-furo-jornal-reage.shtml.

Rafiza Varão is Assistant Professor Tenure of Ethics at the Communication College at the University of Brasília. She coordinates the SOS Imprensa project, the oldest media observatory at that institution, since 2017. She is the coordinator of RENOI (National Network of Press Observatories/Brazil) since 2021. 